\title{
PERCEIVED INFLUENCE OF ENTREPRENEURIAL INTENTION ON BUSINESS SUCCESS OF START-UPS IN FOOD AND BEVERAGE SECTOR OF RIVERS STATE
}

\author{
Onita Uzoma \\ Department of Marketing Education, School of Secondary Education (Business), Federal \\ College of Education (tech.), Omoku.
}

\begin{abstract}
Cite this article:
Onita Uzoma (2021),

Perceived Influence of Entrepreneurial Intention on Business Success of Start-ups in Food and Beverage Sector of Rivers State. British Journal of Management and Marketing Studies 4(3), 87108. DOI: 10.52589/BJMMS969ZWOWH.
\end{abstract}

\section{Manuscript History \\ Received: 18 Aug 2021 \\ Accepted: 8 Sept 2021 \\ Published: 22 Sept 2021}

Copyright $\odot 2020$ The Author(s). This is an Open Access article distributed under the terms of Creative Commons AttributionNonCommercial-NoDerivatives 4.0 International (CC BY-NC-ND 4.0 ), which permits anyone to share, use, reproduce and redistribute in any medium, provided the original author and source are credited.

\begin{abstract}
This study investigated the perceived influence of entrepreneurial intention on the business success of start-ups in the food and beverage sectors in Rivers State. Two specific objectives, two research questions and two hypotheses were formulated to guide the study. A descriptive survey using a quantitative approach was adopted for the study. The population of the study consists of 1,167 small scale businesses across 23 local government areas of Rivers State who are registered with the State Internal Revenue. A sample of 117 small scale business owners in the food and beverage sector of Rivers State was selected using the purposive quota sampling technique. The sample consists of 60 supermarkets and 57 neighbourhood market stores in the business of distributing food and beverages. A self-designed structured questionnaire was used for data collection. The instrument was face validated by the researcher's peers within Federal College of Education (Tech.), Omoku, Rivers State. The instrument was further subjected to reliability using Cronbach alpha to obtain a reliability index of 0.74 and 0.82 for sections $A$ and $B$, with an average index of 0.78 which shows that the instrument is reliable based on data collected from 15 food and beverage start-ups supermarkets and neighbourhood stores from Bayelsa State. Data collected for the study were analyzed using descriptive statistics of mean, cluster means and standard deviation to answer research questions. An independent t-test was used to test the hypotheses raised at a 0.05 level of significance. The major findings of the study revealed that supermarket and neighbourhood market stores startups in the food and beverage sector of Rivers State are of the opinion that entrepreneurial attitude and entrepreneurial experiences help to increase sales volume and enhance customers' retention which was the proxies of business success in this study. The results also show that there is no significant difference in the opinion of the respondents on the perceived influence of entrepreneurial intention on the business success of startups in the food and beverage sector of Rivers State. Based on the findings, it was recommended among others that entrepreneurs who want to succeed in the food and beverage sector of Rivers State should endeavour to render voluntary services in order to accumulate entrepreneurial experiences and develop the right entrepreneurial mindset for success.
\end{abstract}

KEYWORDS: Entrepreneurship, Startups, Customers' Satisfaction, Experience 


\section{INTRODUCTION}

The food and beverages sector in Rivers State, Nigeria is experiencing an increase in the rate of business start-ups especially those involved in wholesale and retailing; hence, there exists stiff competition amongst business owners for success. To succeed, many have delved into entrepreneurial activities; this is because as noted by Hart, Levie and Shasul (2015) entrepreneurial activities are the engines that drive innovation and potency for businesses success in any country. It is for this reason that entrepreneurial activity is seen as one of the most important activities of modern economic life because of its potential to improve opportunities for survival and success (Abdulkarim, Agburuga \& Ordu, 2015). Nevertheless, involvement in any form of entrepreneurial activity does not just come as a mirage; it is driven by the business owner's entrepreneurial intention (Ordu, 2019).

Entrepreneurial intention is attitude driven because it deals with one's propensity to start up an innovative activity capable of solving problems or creating value in return for profit or satisfaction. Supporting this, Zeliha (2015) noted that a person's intention towards entrepreneurship tells us about the intellectual and actual attitudes of the person towards starting an enterprise. Chaudhary (2017) defined entrepreneurial intention as the attitude or preference of an individual to think or act in a way that suggests that they harbour the feeling of venturing into entrepreneurial activities. Ordu (2019) defined entrepreneurial intention as the innate drive to venture into a business to earn a livelihood. This means entrepreneurial intention is the propensity or predisposition to self-employment opportunity. Therefore, through this drive, many business start-ups come into existence.

The entrepreneurial intention has always been considered a relevant subject of entrepreneurial research, especially as it stimulates start-up behaviour. Dahalan, Jaafar, and Rosdi (2015) noted that entrepreneurial intention is developed through experiences and its stability factor is lesser than traits and can change as new experiences are gained or influenced by other factors. Liñán and Fayolle (2015) also noted that entrepreneurial intention is not static; it changes with time and can be influenced by other factors. These positions of early authors imply that one's present entrepreneurial intention does not automatically translate to becoming an entrepreneur as other factors and circumstances could influence the individual to take up or abstain from initial interest in entrepreneurship.

Researchers on entrepreneurial intentions also recognized that it is equally important to study the business success of start-ups (Fayolle \& Liñán, 2014; Knockaert, Foo, Erikson, \& Cools, 2015), given the multifaceted determinant of business success, especially based on the fact that starting up a business has a significant influence on the ability to move towards its success. This means that the entrepreneurial intention of startups in any business sector is critical to their drive for success.

Start-ups in the food and beverage industry represent a major source of a country's economic strength as well as increase household income and consumption demand. According to Ries (2011), start-ups in the food and beverage industry can evidently solve problems in society locally and time-wise in an innovative manner if they adhere to ethical conduct such as discipline, honesty and diligence. Fritsch and Schindele (2011) opined that start-up can be defined by three criteria: new, active and independent business. Startups irrespective of the sector they belong have also been identified as drivers of innovation and socio-economic development and most developing economies depend greatly on them (Ries, 2011). Therefore, 
it is expedient to understand the indices of the success of start-ups particularly in developing markets and growing industries like the food and beverage sector which is deemed very important for human survival in today's highly competitive business world. This is because new, active and independent businesses in the food and beverage sector especially in Rivers State are faced with high competition and challenges which they must be surmounted if they are to be successful.

Success is the desire of every business start-up either measured in financial terms or nonfinancial terms. This is because the motivating factor of starting up a business irrespective of the sector is to realize profit and achieve growth. Supporting this, Bashir and Mahmood (2008) noted that the important goals of a business enterprise are profit maximization, growth achievement in terms of market share and expansion, and sustainability in the market through successful business operations over those of competitors. Tyler (2015) gave the indicators of business success in any sector to include but not limited to net profit margin, growing customers' base and employees' satisfaction with working conditions. Underpinning the importance of employee satisfaction with working conditions, Gorgievski, Ascalan and Stephan (2011) noted that this can translate to product innovation, managing the enterprise effectively and efficiently, doing all the marketing activities aimed at satisfying the customer needs and finally helping the management to acquire and utilize finance so as to maximize the firm's total performance and net worth.

It is worth noting that there are several studies assessing entrepreneurial intention of start-ups, entrepreneurship traits of start-ups and factors affecting business success in the food and beverage sector across the world. However, to the best of the researcher's knowledge, none of the existing studies has considered investigating whether entrepreneurial intention is a determinant of success in the food and beverage sector of Rivers State. Consequently, it is this gap in the literature that led to the conception of the present study.

\section{Statement of the Problem}

The role of start-ups in the food and beverage sector in the growth of a nation's economy cannot be overemphasized as it ignites innovation in the value chain of the food and beverage sector, brings about economic stability and provides job opportunities for many people including minorities, to achieve financial success and independence. Despite this fact, the researcher observes that many start-ups in the food and beverages sectors of Rivers State shut down months after their establishment especially those into wholesale and retail aspects of the food and beverage sector. Their failure is likely due to an unconducive business environment characterized by insecurity, corruption and underdeveloped infrastructures. Early study has also shown that $75 \%$ of start-ups fail in Africa failed due to unconducive business climate (Ghosh \& Nanda, 2010; Food \& Agricultural Organization of the United Nation, FAO, 2019). Nevertheless, there is a plethora of literature on the entrepreneurial intention of start-ups and how it affects their success. However, there is no empirical evidence to the best of the researcher's knowledge that focused on the entrepreneurial intention of start-up and their business success in the food and beverage sector, especially in Rivers State. This implies that no certainty to the claim that entrepreneurial intention influences the business success of startups in the food and beverage sector of the State. This means there is a need to empirically test this affirmation as it relates to start-ups in the food and beverage sector of Rivers State. To this end, this present study aims to determine the influence of entrepreneurial intention on the business success of start-ups in the food and beverage sector of Rivers State. 
British Journal of Management and Marketing Studies

ISSN: 2689-5072

Volume 4, Issue 3, 2021 (pp. 87-108)

www.abjournals.org

\section{Conceptual Framework}

The diagram below represents the dimensions of entrepreneurial intention (independent variable) and business success of start-ups (dependent variable).

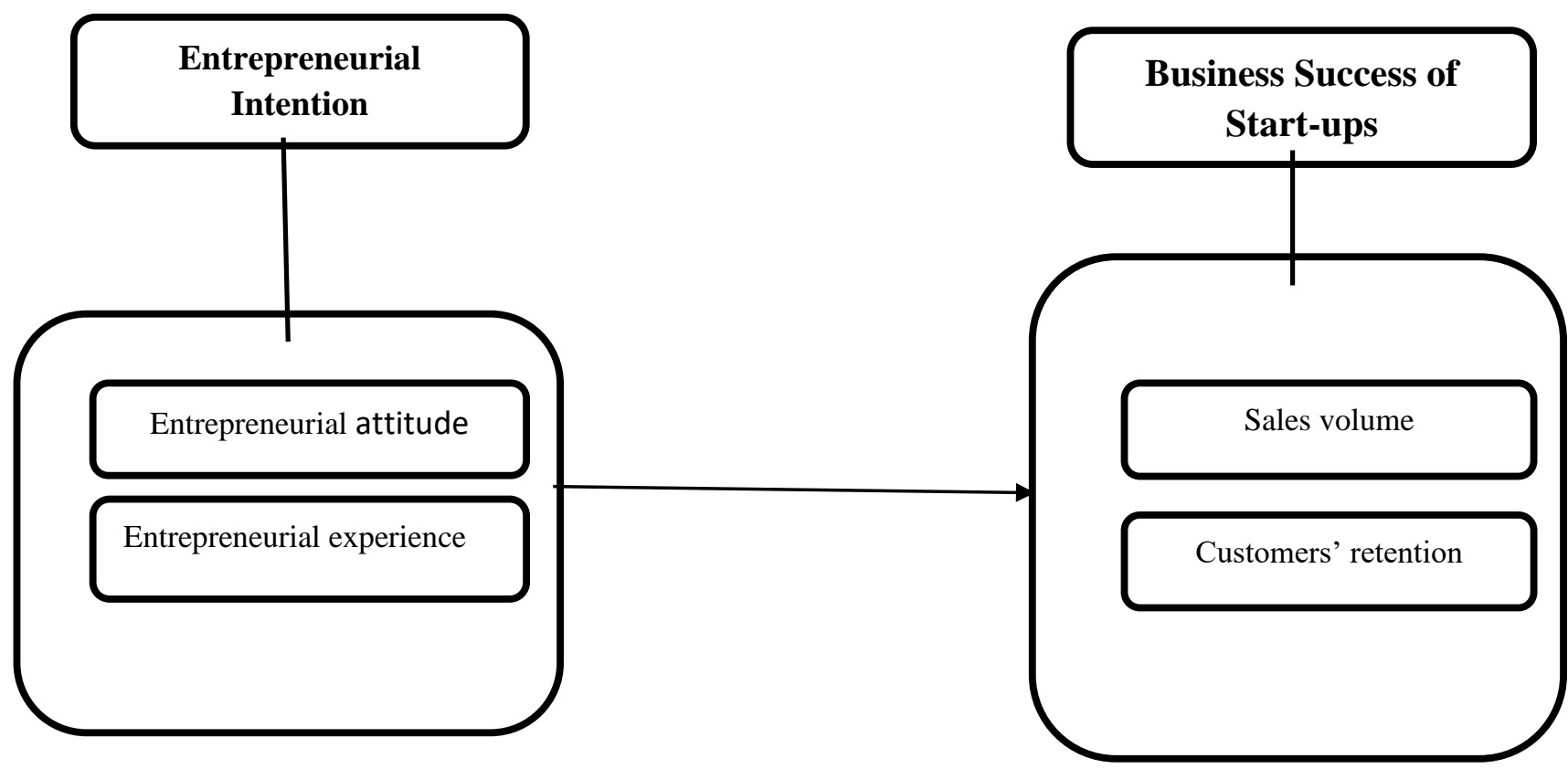

Fig. 2: Conceptual Framework Depicting Dimensions of Entrepreneurial Intention and Business Success of Start-ups

Source: Ajzen (1991) and Tyler (2015).

\section{Objectives of the study}

This study mainly sought to assess the influence of entrepreneurial intention on the business success of start-ups in the food and beverage sector in Rivers State, Nigeria. Specifically, the study seeks:

i. To determine the perceived influence of entrepreneurial attitude on the business success of start-ups in the food and beverage sector of Rivers State.

ii. To determine the perceived influence of entrepreneurial experience on the business success of start-ups in the food and beverage sector of Rivers State. 


\section{Research Questions}

The following research questions guided the study:

i. What is the perceived influence of entrepreneurial attitude on the business success of start-ups in the food and beverage sector of Rivers State?

ii. What is the perceived influence of entrepreneurial experience on the business success of start-ups in the food and beverage sector of Rivers State?

\section{Hypotheses}

The following hypotheses were formulated to guide the study.

Ho1 There is no significant difference in the opinion of supermarket and neighbourhood market stores start-ups on the perceived influence of entrepreneurial attitude on startups business success in the food and beverage sector of Rivers State.

$\mathrm{Ho}_{2}$ There is no significant difference in the opinion of supermarket and neighbourhood market stores start-ups on the perceived influence of entrepreneurial experience on start-ups business success in the food and beverage sector of Rivers State

\section{CONCEPTUAL REVIEW}

In this section, the researcher reviews relevant literature related to the study under sub-headings as follows:

\section{Entrepreneurship and entrepreneurial Intention}

Nations' interest in entrepreneurship has continued to grow due to the many benefits accrued from its practices. According to Brownhilder (2014), entrepreneurship is considered to be a vital tool to solve economic problems particularly unemployment. In the same vein, Kulo and Agbogo (2017) stated that entrepreneurship is the key driver of wealth and jobs creation in any nation. Entrepreneurship equips citizens with the essential entrepreneurial competencies for successful startups and their ability to use these competencies leads to jobs creation by exploiting entrepreneurial opportunities (Abdulkarim, 2019). This means that entrepreneurship is seen as the key ability that an individual needs in order to organize other factors of production and start-up or organize a commercial enterprise, particularly by taking financial risk (Ugwuoke, 2011). Odia and Odia (2013) emphasised this when they asserted that to be successful in entrepreneurship from whatever perspective it is viewed, individuals depend on four major factors namely: knowledge, experience, skills, and attitude (character/integrity).

According to Abdulkarim (2019), entrepreneurship can be viewed from both business and nonbusiness perspectives. The author explained that from the business perspective, entrepreneurship centres on the ability to utilize opportunities to startup new feasible businesses through risk-taking and scarce resource mobilization in order to make a profit; while entrepreneurship from the non-business perceptive centres on improving the value of life and productivity of existing systems through risk-taking to provide a creative reaction to challenges collaboratively and independently. Odia and Odia (2013) asserted that to be successful in 
entrepreneurship from whatever perspective it is viewed, individuals depend on four major factors namely: knowledge, experience, skills, and attitude (character/integrity).

An individual's attitude towards entrepreneurship comes from their innate drive to solve socioeconomic problems. This drive mostly has been associated with the intention to commence an action. This position was supported by Ajzen (1991) theory of planned behaviour which states that intention is a function of three key factors which are: one's perceived attitude towards an act, how one feels people will view the act and the perceived capacity to perform the act. Zeliha (2015) noted that a person's intention towards entrepreneurship tells us about the intellectual and actual attitudes of the person towards starting an enterprise. Chaudhary (2017) defined entrepreneurial intention as the attitude or preference of an individual to think or act in a way that suggests that they harbour the feeling of venturing into entrepreneurial activities. Ordu (2019) defined entrepreneurial intention as the innate drive to venture into a business to earn a livelihood. This means entrepreneurial intention is the propensity or predisposition to selfemployment opportunity. Therefore, within the context of this work, entrepreneurial intention is viewed as a function of perceived attitude towards entrepreneurial activities and entrepreneurial experience. Hence, to determine the entrepreneurial intention of start-up's in the food and beverage sector in Rivers State, their attitude towards entrepreneurial activities and their entrepreneurial experiences was measured.

\section{Start-ups in Food and Beverage Sector}

Start-ups have become desirable entities of every economic sector of a nation. This is because start-ups are seen as innovative platforms through which new products are introduced into the marketplace. Supporting this, Fritsch and Schindele (2011) noted that start-ups can be defined by three criteria: new, active and independent. Graham (2012) defined start-up as follows "a start-up is a company designed for rapid growth." Smolová, Kubová, and Urbancová (2018) defined business start-ups as solution drivers because they come up with innovative means of filling gaps in existing market places as such promotes the new products in a known market or works with the new products in an unknown market.

According to Ries (2011), a start-up brings a new product or service into operation in possible conditions of extreme uncertainty. From the review of the literature in the above section, it is evident that a start-up works on the solution to a problem that is not entirely clear and attempting an innovation which in most cases aimed at filling a gap in the market and works with an entirely new product in a known and an unknown market. The food and beverage sector of Nigeria and Rivers State to be specific has vast opportunities that are yet to be exploited especially as it relates to the value-added chain businesses; hence, start-ups in this sector have vast opportunities to introduce new goods or services. Supporting this, Ali (2016) noted that start-ups in the SMSEs food and beverage sector in Nigeria are well known for the production, packaging and distribution of a broad spectrum of products which includes, spices, poultry, fruits, legumes, vegetables, fisheries, milk and dairy products, alcoholic beverages, grains, raw and processed meats, and speciality products such as cocoa products, soya-based confectionaries, high protein food, mineral water, fast foods etc. Considering the significance of the start-ups in the food and beverage sector of the economy as noted by Sanjeev, and Deepali (2017) in terms of job creation and tax contribution apart from innovation in goods and services, it is important to examine factors that relate to their success. 


\section{Start-ups Success Measurement Dimension}

Success is the motivating factor of most entrepreneurs. According to Ries (2011), countries that have more successful startups tend to have higher economic permanence. This is because they complement the activities of large organizations by providing them with components, services, and distribution of their products (Abdulkarim, 2019). Ries (2011) opined that startup success can be managed and learned. To explain the key start-up success factors, this author uses the diagram below:

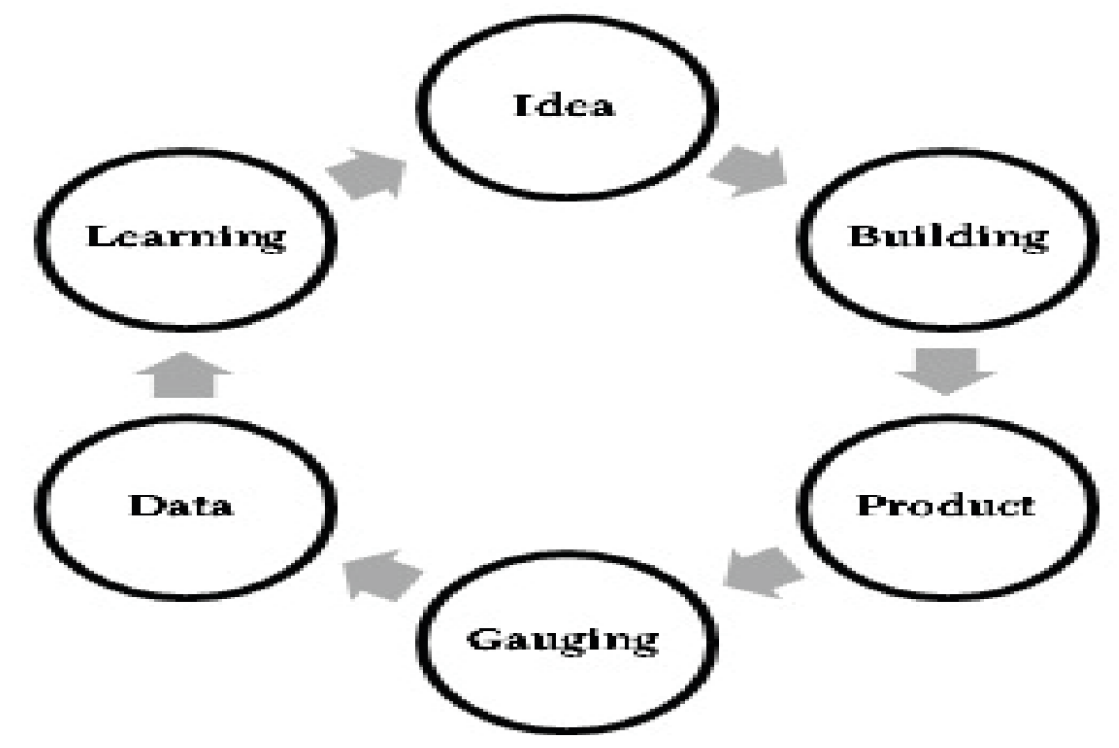

Figure 2: Key Start-up Success Factors

Source: Ries (2011)

In the figure above, Ries (2011) explained learning to be of fundamental significance in new idea generation, which can be referred to as an entrepreneurial vision. Furthermore, according to Ries, it is necessary to create a sample product to acquire important data from its potential market on whether the proposed product is correct or incorrect in solving their problem. The reactions generated would determine whether or not the entrepreneur should learn more and acquire new ideas (or keep the original successful one) and constantly continue in this cycle until a complete entrepreneurial model is formed. Taking this model into consideration, one would conclude that entrepreneurial activities are important to the success of a business since the cyclical model depicts risk-taking leading to product innovation through newly conceived ideas. Supporting this, Tyler (2015) stated that for an entrepreneur to successfully grow a food product from an idea to a sellable item and then into a brand involves making informed choices about goals and parameters for the business itself.

Success from an entrepreneur's perspective may mean different things. According to Bashir and Mahmood (2008), the important success measures to a business entrepreneur are profit maximization, growth achievement, and business sustainability in the market through successful business operations over competitors. The achievement of all these necessitates 
entrepreneurs to focus on serving customers in a better way than the competitors. Gorgievski, Ascalan and Stephan (2011) noted that in business, an entrepreneur can be successful if it realizes the optimal level of performance regarding growth and development. Tyler (2015) outlined some non-financial criteria for measuring success to include:

1. Customers' satisfaction and retention: if customers are not satisfied after buying, they probably will not do it again neither will they refer others to buy (Tyler, 2015), therefore, customers' satisfaction should be given preference in the food and beverage business in order to drive success. Consequently, a growing customer base means your business is meeting target audience needs and creating happy customers who are likely willing to refer others. Business success can be measured through surveys or reviews of the customer base of start-ups.

2. Persistent needs for development and expansion: In business, an enterprise can be considered successful if it realizes the optimal level of performance regarding growth and development. A successful entrepreneur is never satisfied with the present achievement and existing condition of the enterprise. They always seek to progress by continuously improving the existing condition up and up. To this end, they always make reinvestment of a portion of earned profit from the present business for further proliferation of the enterprise. The proportion of profit reinvested for further expansion, mobilization and/or diversification of present business is a good yardstick for determining the success of entrepreneurs.

3. Employee satisfaction: Employees are said to be a critical part of a start-up business. Therefore, start-ups who understand the essence of employees would always consider having a positive and supportive work environment that would motivate employees to do their jobs with pride and efficiency and this is a great model for achieving success, especially in the food and beverage value-added chain business where the employees have direct interactions with customers. Tyler (2015) noted that if the employees feel appreciated, they are more likely to go the extra mile for the customer, which will increase customer satisfaction, and therefore, lead to referrals and new customers. Therefore, conducting annual employees' reviews will go a long way in the determination of their comfort, ability and effectiveness in completing various tasks in the business that can lead to success.

4. Sales volume: Sales volume or frequency can provide data on overall business success. This can be measured by ascertaining sales to new customers, sales to existing customers, profit per sale, which products/services are making the most money, or any other categories that might be important to your business (Tyler, 2015). Keeping track of these numbers can provide valuable insight for other actions.

In the light of the above, within the context of this study, start-up success in the food and beverage sector of Rivers State would be measure from the non-financial indices because most business start-ups will be unwilling to easily provide their financial performance due to security reasons. Nevertheless, the non-financial indices that would be used to measure business success in this study are customers' base and employees' satisfaction. 


\section{THEORETICAL FRAMEWORK}

\section{Theory of Planned Behaviour by Icek Ajzen (1991)}

Ajzen states in the theory of planned behaviour that the stronger the intention of an individual to behave in a particular way, the greater the possibility of behaving in such a way. This means that future human behaviour can be easily predicted through the study on intention to behave in such a manner. The author outlined three key predictors of an individual's intention as: (i.) individual's attitude towards the behaviour, that is, studying whether the individual will perform the act in the future; (ii.) individual's perception of what other people think about the act intended; and (iii.) individual's perception on his capacity to do the act in the future. The explanation can be diagrammatically presented as follows:

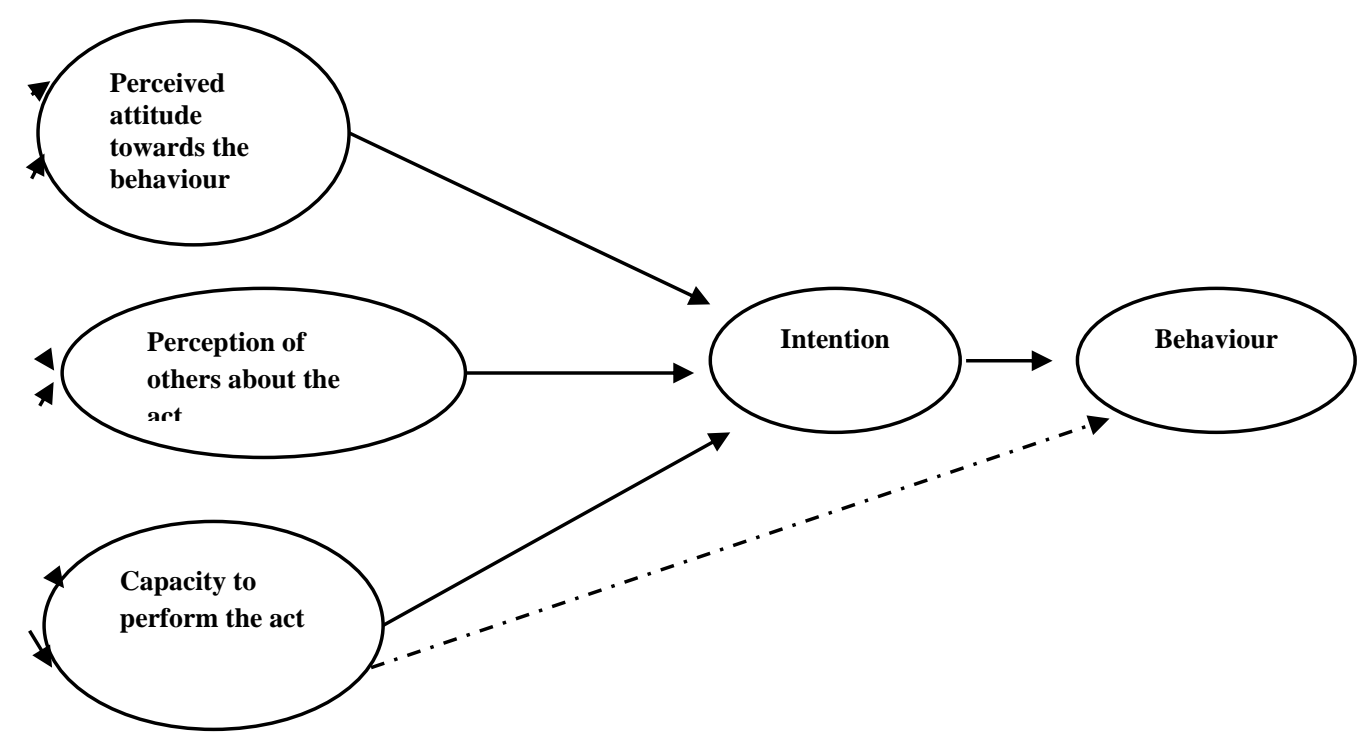

Figure 1: Model of Planned Behaviour

Source: Ajzen (1991)

Figure 1 above shows that intention is a function of three key factors which are: one's perceived attitude towards an act, how one feels people will view the act and the perceived capacity to perform the act. Attitude toward the behaviour measures the degree to which a person has a favourable or unfavourable assessment of self-performance of the behaviour in question. Attitude is determined by the total set of beliefs towards the behaviour based on the perceived benefits. Perception of other people's view of the act refers to an individual's belief of what other people such as family, friends, teachers, religious leaders or significant others would think about the performed act; whether they will praise or rebuke the act when performed. Perceived capacity to do the act refers to the confidence one has in performing the particular act and exercising controls to ensure the success of the act. It is worth noting that confidence in performing acts is mostly influenced by experience. 
In the context of the present study, this theory provides the researcher with the basis for evaluating start-ups' entrepreneurial intentions in the food and beverage sector. However, within the context of this work, the start-ups' entrepreneurial intention would be examined by collecting data on perceived attitude towards entrepreneurial activities and perceived entrepreneurial experience.

\section{Entrepreneurial experience}

According to Sarasvathy and Menon (2013), experiences possessed by the entrepreneurs are a determinant of the success or failure of the firms due to the fact that knowledge acquired by the entrepreneurs in their previous business ventures will play a significant impact on their decision to become entrepreneurs in the future and the management of their new businesses.

On the other hand, the impact of prior work experience and practice may have two different and reverse impacts on entrepreneurial intention; it can give the entrepreneur a set of guiding principles or information helpful to perform better in the business ventures (Fatoki, 2014). This means that business success intentions can be driven by experience-based entrepreneurial activity.

\section{Empirical Review}

Nasip and Sulong (2014) conducted a study on entrepreneurial characteristics and motivation factors of new venture owners: a case in the food-service industry and revealed that internal locus of control, innovation, personal skills and life experiences motives and influence people to develop new businesses. Simon and Watson (2014) conducted a study on the effects of entrepreneurial intention on business performance and the results revealed a positive impact of entrepreneurial intention on the business performance of small, medium scale enterprises. Lim, Yusuf, and Suanda (2017) conducted a study on factors affecting entrepreneurial intentions among students in higher education institutions in northern regions of Malaysia and revealed that attitude towards the behaviour, desirability and feasibility of self-employment, family business background and entrepreneurship education do have significant relationships towards students' entrepreneurial intentions, but not the environmental factor. Smolová, Kubová, and Urbancová (2018) conducted a study on success factors for start-ups related to agriculture, food and nutrition and their relevance to education and revealed that positive attitude towards business, experience, financial literacy, effective time management and effective human resource management are success factors of start-ups. Prada (2020) researched entrepreneurial attitude and business success and the results revealed that the respondents did not promote their business success through the development of entrepreneurial attitude.

\section{Gap in Literature}

The related reviewed empirical works showed that there are several studies conducted to examine one area of entrepreneurship and business performance or success or the other. For instance, a study has been conducted by Nasip and Sulong (2014) to examine entrepreneurial characteristics and motivation factors of new venture owners: a case in the food-service industry. A study has been conducted by Simon and Watson (2014) to examine the effects of entrepreneurial intention on business performance. Lim, Yusuf, and Suanda (2017) have also conducted a study on factors affecting entrepreneurial intentions among students in higher education institutions in northern regions of Malaysia. Smolová, Kubová, and Urbancová (2018) conducted a study on success factors for start-ups related to agriculture, food and 
nutrition and their relevance to education. Prada (2020) researched entrepreneurial attitude and business success. Nevertheless, the researcher has not come across any study focusing on the influence of entrepreneurial intention on the business success of start-ups in the food and beverage sector in Rivers State, hence, it is this gap in the literature that the present study is designed to fill.

\section{METHODS}

\section{Research Design}

The study adopted a descriptive survey research design using a quantitative approach. This research design is deemed appropriate because according to Ezekiel, Oguzor, Onyeukwu, Onwuchekwa and China (2017) when it comes to evaluating the view of respondents on the distinctiveness of definite phenomena in order to draw certain conclusions, a descriptive research design is the most appropriate.

The population of the study consists of 1,167 small scale food and beverage businesses across the 23 local government areas of Rivers State who are registered with the State internal revenue board at end of 2019 (source: Rivers State Board of Internal Revenue). However, for the purpose of this study, only $10 \%$ of the population which is approximately 117 participants selected using the purposive quota sampling technique was used for the study. The sample consists of 60 start-ups owners of supermarkets and 57 neighbourhood market stores across Port-Harcourt, Omoku, Eleme, and Igwuruta selected who are into the distribution and sales of food and beverages in the State.

A structured questionnaire was designed by the researcher tagged "Entrepreneurial intention and Start-ups Business Success Questionnaire (EISBUSQ)". The instrument contains 10 structured items and responses. The 10 items are made up of 5 items to research questions 1 and 2 respectively. The responses to research questions $1 \& 2$ were based on a four-point rating scale of Strongly Agreed (SA - 4points), Agreed (A - 3points), Disagreed (D - 2points) and Strongly Disagreed (SD 1 - point). The instrument was face validated by the researcher's peers within Federal College of Education (Tech.), Omoku, Rivers State. The instrument was further subjected to reliability using Cronbach alpha to obtain a reliability index of 0.74 and 0.82 for the two clusters, with an average index of 0.78 which shows that the instrument is reliable based on data collected from 15 food and beverage start-ups supermarkets and neighbourhood stores from Bayelsa State.

Data collected for the study were analyzed using descriptive statistics of mean, cluster means and standard deviation to answer research questions. An independent t-test was used to test the hypothesis raised at a 0.05 level of significance. The computation was done using was a statistical package for social sciences (SPSS), version 20.0.

Decision rule for mean and grand mean: mean of 3.5 and above will be regarded as Strongly Agreed/Highly Satisfied, 2.5 to 3.49 will be regarded as Agreed/Satisfied, 1.5 to 2.49 will be regarded as Disagreed, and below 1.5 as Strongly Disagreed. In testing the null hypotheses, the decision rule of computation with SPSS was used to draw conclusions regarding the results obtained. The rule states that where the p-value obtained is equal to or less than the $p$-value provided at 0.05 , the null hypothesis be rejected and the alternative hypothesis upheld. 
British Journal of Management and Marketing Studies

ISSN: 2689-5072

Volume 4, Issue 3, 2021 (pp. 87-108)

www.abjournals.org

However, where the $\mathrm{p}$-value obtained from the computation is greater than the $\mathrm{p}$-value provided at 0.05 , the null hypothesis is accepted (Kpolovie, 2011).

\section{RESULTS}

Table 1: Demographic Statistics of Respondents

\begin{tabular}{|c|c|c|c|c|}
\hline \multicolumn{5}{|c|}{ Gender } \\
\hline Variable & & Total & & $\%$ of Total \\
\hline Male & & 48 & & $41 \%$ \\
\hline Female & & 69 & & $59 \%$ \\
\hline Grand total & & 117 & & $100 \%$ \\
\hline \multicolumn{5}{|c|}{ Educational Qualification } \\
\hline \multicolumn{5}{|l|}{ Variables } \\
\hline & Male & Female & Total & $\%$ of Total \\
\hline FSLC/WAEC/SSC & 12 & 22 & 34 & $29 \%$ \\
\hline $\begin{array}{l}\text { NCE/OND/HND/B. } \\
\text { Sc }\end{array}$ & 28 & 43 & 71 & $61 \%$ \\
\hline M.Sc/MBA/Ph.D & 08 & 04 & 12 & $10 \%$ \\
\hline Grand total & 48 & 82 & 117 & $100 \%$ \\
\hline
\end{tabular}

Table 1 shows the gender distribution of male to female out of the total respondents is 48 and 69 respectively. It also shows that those with FSLC/WAEC/SSS are 34 made up of 12 male and 22 female constituting $29 \%$ of the total respondents, those with NCE/OND/HND/B.Sc are 71 made up of 28 male and 43 female constituting $61 \%$ of the total respondents; those with M.Sc/MBA/Ph.D are 12 made up of 08 male and 04 female constituting $09 \%$ of the total respondents. Therefore, the majority of the respondents are holders of NCE/OND/HND/B.Sc which means they are capable of responding to the items of the instrument. 
Research Question 1: What is the perceived influence of entrepreneurial attitude on the business success of start-ups in the food and beverage sector of Rivers State?

Table 2: Summary of Mean and Standard on the Perceived Entrepreneurial Attitude on Start-ups Business Success

\begin{tabular}{|c|c|c|c|c|c|c|c|}
\hline \multirow[t]{2}{*}{$\mathbf{S} / \mathbf{N}$} & \multirow[t]{2}{*}{ ITEMS } & \multicolumn{3}{|c|}{ Supermarket } & \multicolumn{3}{|c|}{$\begin{array}{l}\text { Neighbourhood Market } \\
\text { Stores }\end{array}$} \\
\hline & & Mean & SD & Decision & Mean & SD & Decision \\
\hline 1 & $\begin{array}{l}\text { Examining gaps in food and } \\
\text { beverage supplies before } \\
\text { venturing increases my sales } \\
\text { volume }\end{array}$ & 2.58 & 0.78 & A & 2.95 & 0.71 & $\mathrm{~A}$ \\
\hline 2 & $\begin{array}{l}\text { Searching for new food and } \\
\text { beverage products that can } \\
\text { meet customers' needs } \\
\text { enhances customers' retention }\end{array}$ & 2.68 & 0.73 & A & 2.60 & 0.69 & A \\
\hline 3 & $\begin{array}{l}\text { Searching for a new market } \\
\text { where my food and beverage } \\
\text { products can be distributed } \\
\text { increases sales volume }\end{array}$ & 2.73 & 0.82 & A & 2.65 & 0.77 & A \\
\hline 4. & $\begin{array}{l}\text { Adding value through } \\
\text { repackaging and branding } \\
\text { promote customers' retention. }\end{array}$ & 3.00 & 0.75 & A & 2.60 & 0.74 & $\mathrm{~A}$ \\
\hline 5 & $\begin{array}{l}\text { Recommending to } \\
\text { manufacturers to add new } \\
\text { features to existing food and } \\
\text { beverage product increase sales } \\
\text { volume }\end{array}$ & 2.35 & 0.83 & $\mathrm{D}$ & 2.53 & 0.78 & $\mathrm{~A}$ \\
\hline & cluster mean and standard dev & 2.67 & 0.78 & A & 2.67 & 0.74 & $\mathrm{D}$ \\
\hline
\end{tabular}

Source: 2020 field survey

Table 2 shows that the supermarket and the neighbourhood market stores start-ups in food and beverage agreed that examining gaps in food and beverage supplies before venturing increases their sales volume, searching for new food and beverage products that can meet customers' needs enhances customers' retention, searching for a new market where their food and beverage products can be distributed increases their sales volume and adding value through repackaging and branding promotes customers' retention with mean scores ranging from 2.58 to 3.00 and standard deviation ranging from 0.69 to 0.82 . However, while the supermarket start-ups owners disagreed that recommending to manufacturers to add new features to existing food and beverage products in order to meet customers' needs increases sales with a mean score of 2.35 and a standard deviation score of 0.83 ; the neighbourhood market store start-ups agreed that such recommendation increases sales volume with a mean score of 2.53 and standard deviation of 0.78 . Nevertheless, when the cluster mean and standard deviation of the respondents are considered, it can be concluded that both the supermarket and the neighbourhood market store start-ups agreed that their perceived entrepreneurial attitude 
influences their sales volume and customers' retention which are the proxies of business success in this study.

Research Question 2: What is the perceived influence of entrepreneurial experience on the business success of start-ups in the food and beverage sector of Rivers State?

Table 3: Summary of Mean and Standard on the Perceived Influence of Entrepreneurial Experience on Business Success of Start-ups

\begin{tabular}{|c|c|c|c|c|c|c|c|}
\hline \multirow[t]{2}{*}{$\mathbf{S} / \mathbf{N}$} & \multirow[t]{2}{*}{ ITEMS } & \multicolumn{3}{|c|}{ Supermarket } & \multicolumn{3}{|c|}{$\begin{array}{l}\text { Neighbourhood Market } \\
\text { Stores }\end{array}$} \\
\hline & & Mean & SD & Decision & Mean & SD & Decision \\
\hline 1. & $\begin{array}{l}\text { Experience in identifying gaps in } \\
\text { existing food and beverage } \\
\text { products enhances sales volume }\end{array}$ & 2.50 & 0.71 & $\mathrm{~A}$ & 2.58 & 0.74 & $\mathrm{~A}$ \\
\hline 2. & $\begin{array}{l}\text { Experience in searching for new } \\
\text { markets for food and beverage } \\
\text { products within Rivers state } \\
\text { increases sale volume }\end{array}$ & 2.58 & 0.70 & A & 2.63 & 0.71 & A \\
\hline 3. & $\begin{array}{l}\text { Experience in adding value to } \\
\text { food and beverage product } \\
\text { through branding and packaging } \\
\text { enhance customers' retention }\end{array}$ & 2.69 & 0.71 & A & 2.55 & 0.76 & A \\
\hline 4. & $\begin{array}{l}\text { Experience in identifying new } \\
\text { food and beverage products that } \\
\text { can meet my customers' needs } \\
\text { enhance customer retention. }\end{array}$ & 2.55 & 0.72 & A & 2.53 & 0.78 & A \\
\hline 5 & $\begin{array}{l}\text { Feedbacks on customers' need to } \\
\text { manufacturers help to increase } \\
\text { customers' retention }\end{array}$ & 2.51 & 0.71 & A & 2.72 & 0.75 & A \\
\hline & Grand mean and standard dev & 2.57 & 0.71 & A & 2.60 & 0.75 & A \\
\hline
\end{tabular}

Source: 2020 field survey

Table 3 shows that both supermarket start-ups and the neighbourhood stores start-ups agreed that experience in identifying gaps in existing food and beverage products enhances sales volume, experiences in searching for new markets for food and beverage products within Rivers State increases sales volume, experience in adding value to food and beverage products through branding and packaging enhance customers' retention, experience in identifying new food and beverage product that can meet customers' need enhance customers' retention and feedbacks on customers' need to manufacturers help to increase customers patronage with mean scores ranging from 2.50 to 2.72 and standard deviation ranging from 0.70 to 0.78 . In the same vein, when the cluster mean score and standard deviation are considered, it can be concluded that the respondents agreed that entrepreneurial experience has an influence on startups business success in the food and beverage sector of Rivers State. 


\section{Hypothesis 1}

Ho1 There is no significant difference in the opinion of supermarket and neighbourhood market stores start-ups on the perceived influence of entrepreneurial attitude on start-ups business success in the food and beverage sector of Rivers State.

Table 4: Summary of Independent t-test on the perceived influence of entrepreneurial attitude on start-ups business success in food and beverage retail business in Rivers State on their business success

t-test for Equality of Means

t df Sig. (2- Mean Std. Error 95\% Confidence Interval tailed) Diff Difference of the Difference

\begin{tabular}{llllllllr} 
& & & & & & Lower & Upper \\
\hline \multirow{2}{*}{ VAR00001 } & $\begin{array}{l}\text { Equal } \\
\text { variances } \\
\text { assumed }\end{array}$ & -.48 & 115 & .63 & -.49 & 1.01 & -2.48 & 1.51 \\
& $\begin{array}{l}\text { Equal } \\
\text { variances not } \\
\text { assumed }\end{array}$ & -.48 & 99.459 & .63 & -.49 & 1.02 & -2.50 & 1.53 \\
\hline
\end{tabular}

Table 4 shows $\mathrm{t}=-0.48, \mathrm{df}=115, \mathrm{p}>0.05$ at 0.63 with confidence interval difference at -2.48 and 1.51 for lower and upper level respectively. Therefore, since the p-value calculated at a 2tailed test of 0.63 is greater than the p-value provided at 0.05 , the null hypothesis is accepted. Therefore, it means that there is no significant difference in the opinion of supermarket and neighbourhood market stores start-ups on the perceived influence of entrepreneurial attitude on start-ups business success in the food and beverage sector of Rivers State.

\section{Hypothesis 2}

Ho2 There is no significant difference in the opinion of supermarket and neighbourhood market stores start-ups on the perceived influence of entrepreneurial experience on start-ups business success in the food and beverage sector of Rivers State 
Table 5: Summary of independent t-test on the perceived influence of entrepreneurial experience on the business success of start-ups in the food and beverage sector in Rivers State on their business success.

\begin{tabular}{|c|c|c|c|c|c|c|c|c|}
\hline & & \multicolumn{7}{|c|}{ t-test for Equality of Means } \\
\hline & & \multirow[t]{2}{*}{$\mathrm{t}$} & \multirow[t]{2}{*}{$\mathrm{df}$} & \multirow[t]{2}{*}{$\begin{array}{l}\text { Sig. }(2- \\
\text { tailed) }\end{array}$} & \multirow[t]{2}{*}{$\begin{array}{l}\text { Mean } \\
\text { Diff }\end{array}$} & \multirow[t]{2}{*}{$\begin{array}{l}\text { Std. Error } \\
\text { Diff }\end{array}$} & \multicolumn{2}{|c|}{$\begin{array}{l}95 \% \text { Confidence } \\
\text { Interval of the } \\
\text { Difference }\end{array}$} \\
\hline & & & & & & & Lower & Upper \\
\hline \multirow[b]{2}{*}{ VAR00001 } & $\begin{array}{l}\text { Equal } \\
\text { variances }\end{array}$ & .39 & 115 & .70 & .37 & .94 & -1.49 & 2.23 \\
\hline & $\begin{array}{l}\text { Equal } \\
\text { variances } \\
\text { not assumed }\end{array}$ & .39 & 101.62 & .70 & .37 & .95 & -1.51 & 2.25 \\
\hline
\end{tabular}

Table 5 shows $\mathrm{t}=0.38, \mathrm{df}=115, \mathrm{p}>0.05$ at a 0.70 with confidence interval difference at -1.49 and 2.23 for lower and upper level respectively. Therefore, since the p-value calculated at a $2-$ tailed test of 0.70 is greater than the p-value provided at 0.05 , the null hypothesis is accepted. Therefore, it means that there is no significant difference in the opinion of supermarket and neighbourhood market stores start-ups on the perceived influence of entrepreneurial experience on start-ups business success in the food and beverage sector of Rivers State.

\section{SUMMARY OF MAJOR FINDINGS}

1. Supermarket and the neighbourhood market store start-ups agreed that their perceived entrepreneurial attitude influences their sales volume and customers' retention which are the proxies of business success in this study.

2. Supermarket and the neighbourhood market store start-ups agreed that entrepreneurial experience has an influence on start-ups business success in the food and beverage sector of Rivers State.

3. There is no significant difference in the opinion of supermarket and neighbourhood market stores start-ups on the perceived influence of entrepreneurial attitude on startups business success in the food and beverage sector of Rivers State.

4. There is no significant difference in the opinion of supermarket and neighbourhood market stores start-ups on the perceived influence of entrepreneurial experience on start-ups business success in the food and beverage sector of Rivers State. 


\section{DISCUSSION OF MAJOR FINDINGS}

The finding related to specific objective one shows that supermarket and the neighbourhood market store start-ups agreed that their perceived entrepreneurial attitude influences their sales volume and customers' retention which are the proxies of business success in this study. The results of the hypothesis relating to their opinion also show that there is no significant difference in the opinion of supermarket and neighbourhood market stores start-ups on the perceived influence of entrepreneurial attitude on start-ups business success in the food and beverage sector of Rivers State. These findings emanated from the fact that both respondents agreed that their attitude towards positive entrepreneurial activities increases their sales volume and led to customers' retention. The present findings are supported by the findings of Simon and Watson (2014) when they revealed that entrepreneurial intention measured by attitude has a positive impact on the business performance of small, medium scale enterprises. The findings are also supported by the discovery of Smolová, Kubová, and Urbancová (2018) when they found that positive attitudes towards business and experience are success factors of start-ups. The present findings are contrary to the findings of Prada (2020) who found that the respondents did not promote their business success through the development of entrepreneurial attitude.

The finding related to specific objective two shows supermarkets and neighbourhood market store start-ups agreed that entrepreneurial experience has an influence on start-ups business success in the food and beverage sector of Rivers State. The result of the test of hypothesis related to the objective also shows there is no significant difference in the opinion of supermarket and neighbourhood market stores start-ups on the perceived influence of entrepreneurial experience on start-ups business success in the food and beverage sector of Rivers State. These findings emanated from the fact that both respondents agreed that entrepreneurial experiences increased sales volume and customers' retention which are proxies of business success in this study. The findings of this study are supported by the opinion of Sarasvathy and Menon (2013) when noted that experiences possessed by the entrepreneurs are a determinant of success or failure of the firms due to the fact that knowledge acquired by the entrepreneurs in their previous business ventures plays a significant impact in their future decisions. The findings are also in line with the findings of Smolová, Kubová, and Urbancová (2018) who identified experience as a success factor of start-ups related to the agriculture, food and nutrition sector of the economy.

\section{CONCLUSION}

Based on the findings of this study, it can be concluded that entrepreneurial intention is significant to business success proxies such as sales volume and customers' retention. This is because both entrepreneurial attitude and experience were opined to have increase sales volume and enhance customers' retention of start-ups supermarket and neighbourhood market stores dealing with the distribution of food and beverages in Rivers State.

\section{Implications of the Findings of this Study}

The findings of this study have an implication on the entrepreneurial attitude of all start-ups in the food and beverage sector since positive attitudes towards entrepreneurial activities are capable of increasing sales and retaining customers' base. In addition, there is a need for those 
who want to succeed in this area of business to also develop experiences before venturing into business. Consequently, this calls for the need to attach to successful food and beverage sector entrepreneurs for some time before committing capital to start such a line of business.

\section{RECOMMENDATIONS}

Based on the findings of the study and the conclusion drawn, the following recommendations are put forward:

1. Startups (supermarkets and neighbourhood market stores) in the food and beverage sector in Rivers State should maintain a positive attitude towards entrepreneurial activities in order to be successful.

2. Startups (supermarkets and neighbourhood market stores) in food and beverage should help to promote entrepreneurial experiences through seminars and workshops in order to assist future entrepreneurs to be successful in this line of business.

3. Entrepreneurs who want to succeed in the food and beverage sector of Rivers State should endeavour to render voluntary services in order to accumulate entrepreneurial experiences and develop the right entrepreneurial mindset for success.

\section{REFERENCES}

Abdulkarim, M. A. (2019). Experiential instructions and entrepreneurial skills acquisition. Eastern Europe. Lambert publishing company. Retrieved online from https://www.prospero.hu on $14^{\text {th }}$ August 2020

Abdulkarim, M.; Agburuga, V. \& Ordu, Diseph Pac (2015). Perceived role of students' enterprise on economic empowerment and self-reliance among Business Education students in Rivers State: Nigerian Journal of Business Education: 2 (3): 224 - 233

Ajzen, I. (1991). The theory of planned behaviour reactions and reflections. Psychology and Health 26 (9): 1113-1127. Retrieved online from https://doi.org/10.1080/08870446.2011.613995. on 29th September 2020

Ali J., (2016). Performance of small and medium-sized food and agribusiness enterprises: evidence from Indian firms. International Food and Agribusiness Management Review. 19. 53-64. DOI: 10.22434/IFAMR2016.0024.

Bashir A. B., \& Mahmood O. (2008) Entrepreneurs' economic success index and its influencing factors: an empirical analysis

Brownhilder, N. N. (2014). An assessment of entrepreneurial intention among university students in Cameroon. Mediterranean Journal of Social Sciences, 5(20), 542-55. doi:10.5901/mjss.2014.v5n20p542

Chaudhary, R. (2017). Demographic factors, personality and entrepreneurial inclination: A study among Indian university students. Education+ Training. 59 (2). 171-187.

Dahalan, N., Jaafar, M., \& Rosdi, S. A. (2015). Attitude and entrepreneurial intention among the rural community: the mediating role of entrepreneurial opportunity recognition. Retrieved from http://www.shs-conferences.org on $26^{\text {th }}$ September 2020 
Ezekiel, P. O., Oguzor, I., Onyeukwu, F. O. N., Onwuchekwa, C.A. \& China, M. A. H. (2017). Research techniques in technology education Imo. Great stars publishing international company

Fatoki, O. (2014). Parental and gender effects on the entrepreneurial intention of university students in South Africa. Mediterranean Journal of Social Sciences. 5 (7): 157-162. Retrieved online from https://doi.org/10.5901/mjss.2014.v5n7p157._on 27th September 2020

Fritsch, M. \& Schindele, Y. 2011. The contribution of new business to regional employment - an empirical analysis. Economic Geography. 87(2): 153-180.

Ghosh, S. \& Nanda, R. (2010). Venture capital investment in the clean energy sector. Boston: Harvard Business School.

Gorgievski, M., J., Ascalan, M., \& Stephan, E. U. (2011) Small Business Owners Success Criteria, a Values Approach to Personal Differences. Journal of Small Business Management. 49(2), 207-232

Graham, P. (2012). Want to start a startup? Get funded by Y Combinator. Retrieved online from http://www.paulgraham.com/growth.html on 28th September 2020

Hart, M., Levie, J., \& Shasul, M. K. (2015). Closing the generational start-up Gap. London: RBS Group

Knockaert, M., Foo, M. D., Erikson, T., \& Cools, E. (2015). Growth intentions among research scientists: A cognitive style perspective. Technovation, 38, 64-74.

Kulo, V.A. \& Agbogo, R.A. (2017). Challenges of entrepreneurship education in Nigeria. Nigerian Journal of Business Education. 4(1), 46-52

Lim, F. W., Yusuf, B. N. M. \& Suanda, J. (2017). A study on factors affecting entrepreneurial intentions among students in higher education institutions in northern regions of Malaysia. International Journal of Information Technology and Business Management. 58 (1). 81 - 99.

Liñán, F., \& Fayolle, A. (2015). A systematic literature review on entrepreneurial intentions: citation, thematic analyses, and research agenda. International Entrepreneurship and Management Journal, 11(4), 907-933. doi:10.1007/ s11365-015-0356-5

Nasip, S. \& Sulong, R. S. (2014). Entrepreneurial characteristics and motivation factors of new venture owners: a case in the food-service industry. A conference paper presented at the International Conference on Business Studies at the Faculty of Business, Economics and Accountancy, Universiti Malaysia Sabah, 11 - 15 December. Retrieved online from https://www.researchgate.net/publication/291336946 on 25th September 2020

Odia, J. O. and Odia, A. A. (2013). Developing Entrepreneurial Skills and Transforming Challenges into Opportunities in Nigeria. Journal of Educational and Social Researc. 3(3): $289-298$

Ordu, P. (2019). Influence of activity-based entrepreneurship education on in students' entrepreneurial intention to startup business after graduation from Federal College of Education (Tech.), Omoku- Rivers State. International Journal of Operational Research in Management, Social Sciences \& Education (IJORMSSE). 5 (2). 91 - 103. Retrieved online from http://internationalpolicybrief.org/images/2019/OCTOBER/IJORMSSE/ARTICLE7.pd f on 24th September 2020

Prada, R. (2020). Entrepreneurial attitude and business success. Colombian auto parts sector. Dimensión Empresarial, 18(2). DOI: 10.15665/dem.v18i2.2121 
Ries, E. (2011). The lean startup: how today's entrepreneurs use continuous innovation to create radically successful businesses. New York: Crown Business.

Sanjeev, K. \& Deepali, B. (2017). Factors affecting customer satisfaction of food and beverage outlets- a study of food and beverage outlets between Amritsar and Jalandhar. IOSR Journal Of Humanities And Social Science (IOSR-JHSS). 22 (9). 65-71.

Sarasvathy, S. D., \& Menon, A. R. (2013). Failing firms and successful entrepreneurs : serial entrepreneurship as a temporal portfolio. Small Business Economics. 40. 417-434.

Simon, R. \& Watson, L. (2014). The effects of entrepreneurial intention on business performance. Journal of Governance and Regulation. 3(issue 4). 210 - 222

Smolová, H., Kubová, P., \& Urbancová, H. (2018). Success factors for start-ups related to agriculture, food and nutrition and their relevance to education. Acta Universitatis Agriculturae et Silviculturae Mendelianae Brunensi. 66(3): 791 - 801. Retrieved online through https://doi.org/10.11118/actaun201866030791 on 22nd September 2020

Tyler, T. (2015). How to measure business success. Retrieved online from https://www.verizonconnect.com/resources/article/how-to-measure-business-success/ on $21^{\text {st }}$ September 2020

Ugwuoke, F. N. (2011). Entrepreneurial issues for a functional business education. towards the attainment of national education goals. Multidisciplinary Journal of Research Development 17, 84-88.

Zeliha, K. (2015). Inclination towards entrepreneurship among business students: an empirical study in Turkey. International Journal of Economics, Commerce and Management. III (Issue 7). 16 - 33. Retrieved online from http://ijecm.co.uk/wpcontent/uploads/2015/07/372.pdf on 26th July 2020. 


\section{APPENDIX}

\section{Questionnaire}

Dear Respondents,

Please your assistance is required to generate data for the purpose of completing research on the topic titled "Influence of Entrepreneurial Intention on Business Success of Start-ups in Food and Beverage Sector of Rivers State".

\section{Preliminary Response}

Instruction: Tick the most appropriate option relating to your opinion.

Table 1: Demographic Statistics of Respondents

\begin{tabular}{|c|c|c|}
\hline \multicolumn{3}{|c|}{ Gender } \\
\hline Variable & \multicolumn{2}{|r|}{ Reponses } \\
\hline \multicolumn{3}{|l|}{ Male } \\
\hline \multicolumn{3}{|l|}{ Female } \\
\hline \multicolumn{3}{|l|}{ Grand total } \\
\hline \multicolumn{3}{|c|}{ Educational Qualification } \\
\hline \multirow[t]{2}{*}{ Variables } & & \\
\hline & Male & Female \\
\hline \multicolumn{3}{|l|}{ FSLC/WAEC/SSC } \\
\hline \multicolumn{3}{|l|}{ NCE/OND/HND/B.Sc } \\
\hline \multicolumn{3}{|l|}{ M.Sc/MBA/Ph.D } \\
\hline Grand total & & \\
\hline
\end{tabular}




\section{SECTION A}

Response Options are interpreted as: Strongly Agreed (SA - 4), Agreed (A - 3), Disagreed (D - 2points) and Strongly Disagreed (SD - 1point)

\begin{tabular}{|c|c|c|c|c|c|}
\hline $\mathbf{S} / \mathbf{N}$ & Items & SA & $\mathbf{A}$ & D & SD \\
\hline 1 & $\begin{array}{l}\text { Examining gaps in food and beverage } \\
\text { supplies before venturing increases my } \\
\text { sales volume }\end{array}$ & & & & \\
\hline 2 & $\begin{array}{l}\text { Searching for new food and beverage } \\
\text { products that can meet customers' needs } \\
\text { enhances customers' retention }\end{array}$ & & & & \\
\hline 3 & $\begin{array}{l}\text { Searching for a new market where my } \\
\text { food and beverage products can be } \\
\text { distributed increases sales volume }\end{array}$ & & & & \\
\hline 4. & $\begin{array}{l}\text { Adding value through repackaging and } \\
\text { branding promote customers' retention. }\end{array}$ & & & & \\
\hline 5 & $\begin{array}{l}\text { Recommending to manufacturers to add } \\
\text { new features to existing food and } \\
\text { beverage product increase sales volume }\end{array}$ & & & & \\
\hline
\end{tabular}

Research Question 2: What is the entrepreneurial experience of start-ups in food and beverage retail businesses?

\begin{tabular}{|c|c|c|c|c|c|}
\hline $\mathbf{S} / \mathbf{N}$ & Items & $\mathbf{S A}$ & $\mathbf{A}$ & D & SD \\
\hline 1. & $\begin{array}{l}\text { Experience in identifying gaps in } \\
\text { existing food and beverage products } \\
\text { enhances sales volume }\end{array}$ & & & & \\
\hline 2. & $\begin{array}{l}\text { Experience in searching for new markets } \\
\text { for food and beverage products within } \\
\text { Rivers state increases sale volume }\end{array}$ & & & & \\
\hline 3. & $\begin{array}{l}\text { Experience in adding value to food and } \\
\text { beverage product through branding and } \\
\text { packaging enhance customers' retention }\end{array}$ & & & & \\
\hline 4. & $\begin{array}{l}\text { Experience in identifying new food and } \\
\text { beverage products that can meet my } \\
\text { customers' needs enhance customers' } \\
\text { retention. }\end{array}$ & & & & \\
\hline & $\begin{array}{l}\text { Feedbacks on customers' need to } \\
\text { manufacturers help to increase } \\
\text { customers' retention }\end{array}$ & & & & \\
\hline
\end{tabular}

